\title{
Childbirth Rhythms and Childbirth Ritual in Early Modern Spain, together with some Comments on the Virtues of Midwives ${ }^{\top}$ \\ Ritmos y ritual del parto en el Siglo de Oro, junto con algunos comentarios sobre la virtud de las comadronas
}

\section{Wolfram Aichinger}

Universität Wien

AUSTRIA

wolfram.aichinger@univie.ac.at

[Hipogrifo, (issn: 2328-1308), 6.1, 2018, pp. 391-415]

Recibido: 02-02-2018/ Aceptado: 01-03-2018

DOI: http://dx.doi.org/10.13035/H.2018.06.01.29

Abstract. Childbirth in Early Modern Spain can be viewed as an area where ignorant midwives and cruel doctors ruled over terrified women who, deprived of all choices, were condemned to passively endure the ordeal of parturition. Medical and judicial sources seem to strengthen this vision.

Yet, when we apply Mary Douglas's theory of ritual, another picture emerges which might be just as valid for wide sections of social experience. Consequently, this article concentrates on the social rhythms of birth. It will touch on relics, the Rose of Jericho, delivery as a shared experience, on birthing positions, role playing and the stories which were brought back to the memory of parturient women, es-

1. This study is part of the research project El Calderón cómico, funded by the FWF Austrian Science Fund, project number P 29115. It was carried out in collaboration with Nina Kremmel, Hannah FischerMonzón and Esther Zitterl. I am very grateful to José Aragüés Aldaz, Jesús M. Usunáriz, María Cruz de Carlos Varona, Laura Oliván, Adrián Wilson, Alice Dulmovits, Alberica Barbolani di Montauto, Andrea Sommer-Mathis, Fernando Rodríguez-Gallego, Germán Vega and Fernando Sanz for their generous help and advice. 
pecially those about Saint Mary, imagined as a midwife and a powerful assistant who comes to the rescue of sinners.

Doctors from Golden Age Spain, it appears, appreciated the knowledge and skills of midwives. Even though they tried to curtail some rituals and wrote against witchcraft, they did not want to do away with the institution of female midwifery.

Keywords. Ritual; Mary Douglas; Cinta de Tortosa; Rose of Jericho; Midwives; Nuns; Obstetricians; Labour; Birth pain; Rhythm; Jaculatorias; Community; Birthing position; Birthing stool; Clinging; Marian miracles; Gonzalo de Berceo; Nuestra Señora de Guadalupe; Mental images; Francisco Santos; Doctors; Midwives.

Resumen. El parto en el Siglo de Oro puede presentarse como un área donde parteras ignorantes y médicos crueles gobernaron sobre la vida de mujeres quienes, sin voz ni poder, estaban condenadas a sufrir y a aguantar. Las fuentes médicas y jurídicas parecen confirmar esta visión.

Sin embargo, si aplicamos las tesis de Mary Douglas sobre la función social del ritual, otra imagen emerge, una imagen que podría ser tan válida para grandes secciones de la sociedad como la primera. En consecuencia, este estudio se centrará en los ritmos sociales y culturales del parto. Tratará de reliquias, de la Rosa de Jericó, del parto como experiencia compartida, de posturas de parto, de formas parateatrales y de las historias que se solían aducir para edificar a la parturienta; destacan entre estas historias aquellas en que la Virgen María hace de comadrona y viene a socorrer a madres pecadoras.

Los médicos de la época, según parece, apreciaron los conocimientos y el arte de las comadronas. Si bien escribieron contra las hechiceras y criticaron ciertos rituales, no hubo una clara intención de acabar con la asistencia femenina durante el parto.

Palabras clave. Ritual; Mary Douglas; cinta de Tortosa; Rosa de Jericó; comadres; monjas; obstetricia; dolores de parto; ritmo; jaculatoria; comunidad; postura de parto; silla de parir; asirse a alguien; milagros de la Virgen; Gonzalo de Berceo; Nuestra Señora de Guadalupe; imágenes mentales; Francisco Santos; médicos; comadronas. 
to Gabriela Winiger, the midwife

\section{INTRODUCTION: CHILDBIRTH RHYTHMS ${ }^{2}$ AND SHARED CULTURE IN GOLDEN AGE SPAIN}

The great events of the human life cycle -birth, marriage, death- are lived in community. It therefore behoves the community to offer, even to impose, narratives, rituals and symbols which are meant to accompany these occurrences. Early Modern Spain provides a rich field for studying these expressions of culture. Recent publications have collected much evidence about the use of images, relics, holy words and incantations before and during pregnancy, in the birth chamber and in the postpartum period. Our study of objects and images in their context gives us an idea about what these practices meant to contemporary people and how they were related to their deepest concerns ${ }^{3}$. I would like to take up this line of research and focus on one specific problem: the rhythms of the body and the rhythms introduced by ritualistic practice, or: the intended synchronization of «body» and «culture» in the very process of parturition. This is certainly a risky endeavour and the subject I deal with an elusive one. Chroniclers do not normally dwell on the details of delivery and we have no reports on the step by step succession of gestures and actions carried out by the mother, the midwife and other personnel involved. Nevertheless, the sources we have seem to be explicit enough so as to forward some theses and to outline some general trends. I will draw on different kinds of testimonies: medical treatises which also comment on the role and importance of midwives; hagiographic texts, sources from court life (personal letters and diaries), visual and material sources such as paintings, sculptures or relics, fictional texts such as novels and drama, the writings of contemporary chroniclers and historians.

There is one major cognitive barrier which separates us from our fellow humans living in the Spanish Golden Age. Our view of ritual is «bedevilled» by the materialism and rationalism of our time $\mathrm{A}^{4}$. By contrast, early modern Spaniards could neither think function nor utility in a strictly scientific or pragmatic way. They just did not know modern standards and modern concepts of body, life, medicine or health. We are tempted to concede a merely ornamental function to rituals. They seem to be no more than «background music» that accompanies or comments on the matters of real and tangible importance. The forms and variations of ritual appear to be arbitrary and subject to myriad variations which are governed by tradition, fashion or taste. The way in which the dead are buried does not seem to have an impact on death itself, the decoration of a birthday cake does not profoundly change the

2. I will limit myself to the very process of childbirth and will not touch upon the way in which fertility and maternity was connected to the rhythms of the moon, the tides of the sea, the seasons of the year (Bennassar 1985, p. 422, for rural areas of Early modern Europe, Bonnet, 1988). Let me just briefly recall that the question of chronobiology enjoys increasing scientific interest, a fact reflected in the granting of last year's (2017) Nobel Prize in Physiology or Medicine to three specialist in the field of biological rhythms. 3. See Carlos Varona, 2006, 2007 and 2008, Usunáriz, 1999 and 2016; for early modern England, Wilson, 2013

4. Douglas, 2002, p. 36 
perception of the celebration. True devotion in religion does not appear to depend on images or holy objects.

\subsection{Mary Douglas's reappraisal of ritual}

Back in the 1960s, the British anthropologist Mary Douglas launched an attack against this narrow and superficial view of ritual. According to Douglas, anti-ritualist prejudice and bias are characteristics of our time and it is precisely this bias which blocks our way to an understanding of foreign or past communities. Consequently, Douglas devotes some of her most inspired pages to the task of working out the cognitive and social importance of symbols and ritualist behaviour. Rituals, she asserts, not only reflect or colour human action, they are an essential part of social life. Through rituals, Douglas says, we create a frame that singles out certain matters in time and space. In this act of framing some specific issues are selected and highlighted for shared attention while others are downgraded by the very act of exclusion. Ritual thus establishes criteria for collective perception. It imprints the elements displayed in a ritual context on the memories of participants, thereby creating links between the past, the present and the future. In short, the power of ritual and symbolic actions derives from their capacity to bring behaviour under the control of external, visible signs ${ }^{5}$. Rituals thus shape and condition experience. They can even correct and re-formulate past experience in the language of dominant (or also subversive or repressed) cultural scripts and values ${ }^{6}$.

\section{CHILDBIRTH RITUALS}

Childbirth rituals certainly provide a very special arena for testing Douglas' approach. These rituals are meant to work upon a human body in a moment of extreme challenge. It even seems that the female body itself is staging the event without bothering to give precise information about the beginning and the ending of the performance ${ }^{7}$. The drama of birth can unfold in time even without human assistance. And this drama bears some resemblance to men-made rites: there is a lapse of time quite clearly marked by a beginning, the onset of labour and an ending, the birth of the baby if things go as expected. There is rhythm and there is a climactic movement towards an inevitable resolution. There are lots of tension and

5. «Not only does ritual aid us in selecting experiences for concentrated attention. It is also creative at the level of performance. For an external symbol can mysteriously help the co-ordination of brain and body. Actors' memoirs frequently recount cases in which a material symbol conveys effective power: the actor knows his part, he knows exactly how he wants to interpret it. But an intellectual knowing of what is to be done is not enough to produce the action. He tries continually and fails. One day some prop is passed to him, a hat or green umbrella, and with this symbol suddenly knowledge and intention are realised in the flawless performance» (Douglas, 2002, pp. 78-79).

6. Douglas, 2002, pp. 82-83.

7. The question of the interplay of body and culture in childbirth was raised for instance by Laget, 1977, p. 958. See also Usunáriz, 1999, pp. 329-330. 
suspense. The trance and altered state of mind which so many rituals aim at are brought about in the mother's mind by «hormonally driven processes» ${ }^{8}$.

\subsection{In touch}

How then, are body and culture brought to work in concert in Early Modern Spain? Some childbirth rituals of Medieval or Early Modern Spain aim at directly affecting the body: relics are placed on women's wombs ${ }^{9}$ or girdles imprinted with holy words, are put on their bellies ${ }^{10}$. The cathedral of Tortosa, for example, pretended to guard a holy girdle which the Virgin had fabricated herself and handed over to a devotee during an apparition. From the year of 1629, when prince Baltasar Carlos was born, the holy object was transferred from Tortosa to the court of Madrid, every time childbirth in the royal family was approaching ${ }^{11}$. Today, we perceive relics as isolated items, slightly spooky and exposed for the edification of a few devotees and masses of ignorant tourists who gather in front of the impressive collections kept in the Monasterio de las Descalzas Reales or de la Encarnación in Madrid. But in ancient times they were elements in a whole network of gestures and narratives. And it was these practices and narratives that made them meaningful and effective. They reminded people of a «common myth» ${ }^{12}$ and of the believed power that its central figure, the Virgin, could exert over human plights. Holy objects were not perceived as static items, they unfolded their full cultural energy when they became part of a ritual context, in which a narrative was recalled and put to the service of a pressing issue.

\subsection{Time, Rhythm, Communion}

When childbirth is concerned, time and rhythm deserve special scholarly attention: Rites run parallel to a physiological process and this process in its intensity and specific timing stands out among all other processes a healthy body can undergo ${ }^{13}$. It is difficult to find an accurate expression and generalisations are prob-

8. Sakala, Romano and Buckley, 2016, p. 264, Schmid, 2011, p. 31. Jennifer Worth speaks of the «curious in-turned look that a woman has at this time [the second stage of labour W. A.] as she concentrates every ounce of her mental and physical strength on her body, and on the miracle, she is about to bring forth» (Worth, 2002, p. 11).

9. Working at the level of associative thinking and in the tradition of classical authors it was also usual to put a living rabbit on the mother-to-be's breast «como dice Philostrato» (Núñez, Libro del parto humano, fol. 46r).

10. Rodríguez, 2000 , p. 505

11. Vidal Franquet, 2008, p. 25, about the origins and history of the cult in Early Modern Spain, pp. 24-30. For the relation established between the Virgen de la Cinta and the Casa Real see Bayerri y Bertomeu, 1989, pp. 147-152 and Gil Saura, 2008, pp. 105-106.

12. Harari, 2014, pp. 27-36, 126-133.

13. In that sense childbirth ritual can only be compared to rituals performed during the process of dying. Most childbirth rituals disappeared when childbirth was transferred to hospitals. Rituals of dying were abolished when death in a hospital became a lengthy transition commanded by medical technologies (Ariès, 1975, pp. 213-220). 
lematic where we can observe a wide range of personal experiences. Some view childbirth as a moment of supreme female power and empowerment ${ }^{14}$, and indeed, whoever witnesses childbirth labour might be impressed by the forces untied by the contractions of the womb, which seem to be rolling along like ocean waves. But these powers are also described as overwhelming a woman as if the energies unleashed came from somewhere outside her ${ }^{15}$. These powers are largely out of conscious control and beyond the influence of willpower ${ }^{16}$, causing considerable pain ${ }^{17}$. Thus, empowerment seems to come hand in hand with exposure, risk, danger and vulnerability ${ }^{18}$. However, we can confidently state that childbirth assistance is all about timing and rhythm. The competence of midwives and doctors depends on their correct interpretation of signs that indicate the stage of parturition and induce a wise collaborator to adopt specific measures to accelerate it, to slow it down, or, if this seems more pertinent, just to wait and let nature take its course ${ }^{19}$. Early modern treatises on childbirth repeatedly insist on this point: A good midwife needs a sharp sense of time and rhythm. This is first and foremost what makes for her wisdom, prudence ${ }^{20}$ and ingenuity ${ }^{21}$.

Through certain acts and ceremonies, a midwife could (and still can) «conjure» time and encourage the process of opening, transition and expulsion. There was a strange plant, coarse and unimpressive upon first sight, but endowed with the aura of the Holy Land and the capacity of mimicking the course of childbirth, thereby responding to human command: the Rose of Jericho. This species can survive without water for a long time, taking the appearance of a spherical bundle of dried leaves which notwithstanding uncurl and open whenever water is sprinkled on them. The process takes several hours and can therefore very well be set as a paragon for the desired length of delivery. It suggests, as sympathetic magic does,

\footnotetext{
14. This argument has also been forwarded with respect to Spanish queens (Sánchez, 1998, pp. 165166,177 and fig. 2, 3, 4.)

15. A perception related by experienced midwives. See e.g. the BBC-documental «Medieval Lives. Birth, Marriage, Death» (2013), written by Helen Castor.

16. In his treatise dating from 1580, Francisco Núñez speaks of the «assault of birth», «asalto del parto» (Núñez, Libro del parto humano, fol. 40r). The anonymous narrator of Lazarillo de Tormes uses the expression «tomóle el parto» (p. 14), with reference to his mother's unplanned delivery by the riverside. 17. A fact that is in some way «canonized» and established as an atemporal constant by the famous passage in the book Genesis. It is worth noting the different value and effect that specific periods or even ideologies attribute to this phenomenon. According to José María Gironella, during the Spanish Civil War, Russian nurses travelled through the Republican zone and held lectures on painless birth. Traditional Catholic wives were shocked. For them, without pain in parturition no loving bond could be created between a mother and her child (Gironella, 1994, pp. 359, 479). A male 17th century author says that in the straits of childbirth pain «[...] levántase por el cuerpo una manera de horror febril, de la fuerza que hace la naturaleza para la expulsión» (Ruices de Fontecha, Diez privilegios para mujeres preñadas, fol. 113r). 18. For vulnerability see e.g. Butler, 2006.

19. Gélis (1989, p. 210) holds that whereas midwives were keen to shorten the process, obstetricians were more inclined to give time to time.

20. «Ha de ser sobria, para que aguarde el tiempo que es justo estar queda, y conocer, y acudir, cuando ocurre la necesidad, y no antes.» (Ruices de Fontecha, Diez privilegios para mujeres preñadas, fol. 108r.) 21. Ruices de Fontecha, Diez privilegios para mujeres preñadas, fol. 108r-v.
} 
an analogy between the object and a bodily process. Suzy Knight points out that the «process of closing and opening [performed by these plants. W. A.], dying and coming back to life, doubtless seemed miraculous to those who witnessed it for the first time»22. «lt was [...] in the East», she explains,

that the Rose of Jericho was first used as a birthing aid. Then, as now, Muslim women in the Middle East used it to speed up childbirth. [...] The Franciscans who conducted the pilgrimage tours of the Holy Land soon began to promote this usage. By the sixteenth century, they too had started selling Roses of Jericho and claimed that they only opened on Christmas Eve or when women were in labour, and at no other time. [...] the friars now interpreted the strange properties of the plant as a living manifestation of the miracle of the opening and closing of the Virgin's womb. Whilst northern Europeans focused on this aspect, calling Anastatica the Christmas Rose, it was the help that it promised to women in labour that captured the imagination of Italian mothers ${ }^{23}$.

The association with the birth of the Virgin was confirmed through legends and the re-naming of the flower, which was now also called Rose of Saint Mary 24 .

Historians of ancient Madrid relate this strange rose to one of the town's famous midwives, one so called comadre de Granada, «probablemente, de raza gitana y de nombre Amparo» ${ }^{25}$. This woman lived at the end of the 16th and in the early 17th century. Purportedly, she attended deliveries both at court and in her neighbourhood, gaining such reputation as a midwife that even a street in the Lavapiés area was named after her. The Rose of Jericho was among the utensils and objects that she carried in her toolkit when rushing off to childbirth. Was she the first to introduce the oriental plant in the capital of Spain? The first to make it popular in the homes of less well-to-do people?26. Unfortunately, references to «la comadre de Granada» in the studies we have got at hand are not coherent ${ }^{27}$. Both the full stories of this preeminent professional and her role in the introduction and dissemination of the Rose of Jericho are still to be written.

22. Knight, 2010.

23. Knight, 2010 , p. 141

24. Knight, 2010, p. 140. A similar manipulative faculty was ascribed to candles. When consecrated candles were placed beside the prospective mother, a message was conveyed: Your pain will not last forever, it will last no longer than the flame needs to consume the wax (Salvador, 1764, pp. 353-354). Candles received the names of saints or of significant attributes of the Virgin: «Nuestra Señora de la Consolación», «Nuestra Señora de la Luz» (Rodríguez, 2000, p. 511). For 15th century Aragón also see García Herrero, 1989, p. 291.

25. Huertas Vázquez, 1996, p. 530, Répide, 1971, p. 37. She also employed flowers which were watered and put in front of an image of the Virgin Mary. Again, this conveyed the idea that by the time the flower was in full blossom the infant should have been born. As for the use of this plant in Latin America see Rodríguez, 2000, p. 510. For 20th century rural Spain, see Domínguez Moreno, 1986, p. 10.

26. In Renaissance Florence, the Rose of Jericho «for women in labour» is listed among highly treasured objects in the households of the social elites (Knight, 2010, pp. 134-135).

27. One Catalina López de Moya, known as la comadre de Granada, testifies at a canonization process at the end of the 16th or beginning of the 17th (Bleda, Vida y milagros del glorioso San Isidro el Labrador, p. 60). See also Martínez Kleiser, 1926, p. 34. 
In any case, by the middle of the century, gentlemen at the royal court of Madrid still considered the Rose of Jericho a gift worth mentioning. And in the complicated ceremonies of mutual favours and attentions, it was a gift specially suited for expecting women. A case in point is the diary kept by the Austrian Ambassador, count Franz Eusebius von Pötting: in April 1664, his wife, the princess Marie Sophie von Dietrichstein, was with child. Twice, on the fourth and the sixth of that month, Pötting noted in his journal that dignitaries who came to see him presented a Rose of Jericho to his wife ${ }^{28 .}$

The process of unclasping and releasing could also be expressed with laces, girdles or cords. Thus, in rural Spain, it was until recent decades that the process of delivery was echoed and enhanced by the opening of shoelaces, girdles or knots in the birthing room. Not only the parturient but also the assisting women wore their hair loose ${ }^{29}$. Again, ritual «framed» a period of time and guided ideas by placing them under the control of visual signs ${ }^{30}$.

\subsection{Voces and jaculatorias. Shared rhythm, clinging and the soundscape of birth}

Isabel de Portugal married King Carlos I of Spain in 1526 and gave birth to the future King, Philip II, on the 21 st of May 1527. A Spanish historiographer gives us a concise account of how the queen endured the time of her travail:

Una multitud se congrega alrededor del palacio donde habitan los emperadores. En su interior, Isabel ha ordenado cerrar las ventanas y dejar su cuarto en penumbra para preservar su intimidad durante el trance. La comadrona, Quirce de Toledo, trata de aliviarla y la anima a gritar como cualquier parturienta. «Eu morrerey, mais nao gritarey», le espeta la emperatriz, que solicita le coloquen un ligero pañuelo sobre la cara para que su rostro desencajado no sea visible ante sus damas ni los médicos ${ }^{31}$.

28. At the same period, she visits the most prominent altars consecrated to the Virgin, among them Nuestra Señora del Buen Alumbramiento in the parish church of San Martín (Nieto Nuño, 1990, pp. 2627). For the Rose as a deluxe article see also Lindorfer, 2009, p. 74. Lope de Vega presents the Rose of Jericho as an item which an old neighbour and go-between, who seems well acquainted with the ordeal of childbirth, would take to an impending birth in Madrid. His testimony dates from 1632 and pretends to recreate the usages and habits of the early 17 th century. It is the dialogue novel La Dorotea. So the use of theses roses seems to be well established in the Siglo de Oro, but nevertheless worth to be mentioned as an outstanding birthing aid (Lope de Vega, La Dorotea, p, 182 and n. 149 where the editor refers to early modern botanical treatises and the attribution of the usage to «superstitious women» in the eighteenth century). The expression, however, does not appear in the Tesoro de la lengua castellana by Sebastián de Covarrubias in 1611.

29. Domínguez Moreno, 1986, p. 13. The impression of a mother-to-be's dishevelled hair, moist with perspiration, is also reported by Lope de Vega in a play written at the beginning of the 17th century (Lope de Vega, El mayorazgo dudoso, p. 107).

30. Douglas, 2002, pp. 78-79.

31. Rubio, 2010 , p. 86. 
«Eu morrerey, mais nao gritarey» - «l shall die, but I will not scream»: this is probably the most famous phrase reported from a royal birthing chamber in the times of the Spanish Casa de Austria. Urged by the midwife to facilitate the transition of the infant by opening her mouth and throat and by setting her vocal chords into vibration, the dignified Portuguese retorted that she would rather die than to give up a queen-like composure ${ }^{32}$. This attitude impressed people at court; it was subsequently remembered and retold by other authors of the age and presented as a paragon for the next generations of queens ${ }^{33}$.

It testifies to the social pressures that weighed on a Habsburg queen. Moreover, it shows the way in which a first lady could spurn her midwife's advice, thus distinguishing herself from what a plebeian woman would do. So it also gives valuable insight into the attitudes of common people. What did they deem an appropriate expression of physical pain? Were screaming and the energy produced by it recommendable ways of encouraging birth? They obviously were and doctors did not disagree with this proceeding. In his treatise on childbirth, Francisco Núñez writes in 1580:

[...] conviene que la preñada algún tanto esté asentada, como espacio de una hora, y que luego se torne a levantar, y suba y descienda por algunas gradas, y que voceando y gritando sin pereza [italics W. A.], se menee a una y otra parte ${ }^{34}$.

Mothers used to scream during childbirth, at least since the days in which prophets and biblical authors noted it. Screaming at childbirth is a feature that distinguishes the human species from other primates, marking the final effort on the mother's side and preceding the first audible signs of the new-born baby ${ }^{35}$. But these archaic expressions were nevertheless connected to culture through the vowels and the consonants of holy words. These words were parts of prayers, especially of ejaculations (in the religious sense of the word). Their objective was to bargain for the help of saints, specifically that of San Ramón Nonato ${ }^{36}$, Saint Margaret and Saint Mary. Golden Age theatre provides us with scenes which might echo their form and sound patterns. Lope de Vega supplies us with a case in point. He does so in his work El príncipe despeñado, a play in which he represents the life of a medieval queen who turns to the Virgin in the labour of childbirth. Her ordeal is all the more exhausting as she has been expelled from her palace by a mean brother-in-law, the king having died during her pregnancy. She has to undergo birth in the mountain wilderness of Navarra:

¡Virgen del parto! Mirad

Que la noche de Belén

no hallávades vos también

32. She did not die this time, but died after the premature birth of her fifth child in 1539.

33. See for instance Diego de Guzmán, Vida y muerte de Doña Margarita de Austria Reina de España, fols. 223v-224r.

34. Núñez, Libro del parto humano, fol. 28r.

35. Mentioned for instance in Lope de Vega's play El mayorazgo dudoso, p. 107.

36. See also Rodríguez, 2000, p. 506. 
casa, huésped ni piedad,

¡Señora, doleos de mí!

Some verses later, pangs of labour set in again:

¡Ay Virgen piadosa! ${ }^{37}$

Ethnography from 20th century rural Spain offers us another prayer, which might bear similarity to the ones pronounced in earlier centuries. Interestingly, it has the form of a litany, in which a group of praying people responds to the woman in labour. The author of the study describes the rite as follows:

Al intensificarse los dolores del parto es costumbre en Ahigal [a village in the Spanish province of Cáceres] que una mujer puehta en ehtah cuhtionih rece la correspondiente jaculatoria:

San Ramón benditu,

Que sin huerza de muhel nacihti

Y con l'ayúa del tu padrinu

Al mundu benihti. Amén

A ello responden las otras mujeres que auxilian a la parturienta:

San Ramón, santu barón, que lo para sin dolol ${ }^{38}$

There are two elements which should be underlined for our purpose: Rhythm and communion. The chorus of women repeats and enhances the expectant mother's supplication, it «backs her up», metaphorically and almost literally; a strong tie between both parts is established.

\subsubsection{To hold on to somebody}

This was even more so, when the power of words came across not only through sound but also through physical contact. At this point we should briefly comment on the habitual birthing positions. Medieval and early modern authors advocate a posture where the womb remained in a vertical position. Therefore, the childbearing

37. Lope de Vega, El príncipe despeñado, pp. 118-119 and 121, vv. 835-839 and 904. See also Aichinger, 2015.

38. Domínguez Moreno, 2010, pp. 3-4. According to the author of the study, village people in Extremadura assigned great efficacy to this form of prayer. For the rhythm created by women who attend delivery see also Gélis, 1989, p. 159. San Ramón Nonato (AD 1220-1260), who was extracted from the womb of his mother after she had died, already in the 16th and 17th centuries was the most important patron saint of parturient women, overshadowed by the Virgin and in close competition with Saint Margaret (Rodríguez, 2000, p. 506) 
woman should sit, kneel, squat ${ }^{39}$ or -as Fontecha recommends for buxom women- be on all fours while delivering ${ }^{40}$. She had to be sustained by her assistants, normally two women, who held her under the armpits ${ }^{41}$. The person who held her from behind could also be a man with the woman slinging her hands around his neck ${ }^{42}$. The use of a birthing stool is recommended by Francisco Núñez in 1580. However, while praising the advantages, he attributes its use mainly to French, German and Italian midwives ${ }^{43}$. In 1606, Ruices de Fontecha mentions both methods, birth with or without a stool ${ }^{44}$. Neither doctors nor midwives seem to have insisted on one specific method. Yet they all emphasize the active part a healthy body should take in the process. What is more, according to these voices the childbearing body did not remain unsupported ${ }^{45}$ and untouched during delivery. There is a good deal of evidence that this meant a lot to women involved in childbirth. Once again, it is Lope de Vega who gives us important clues ${ }^{46}$. This is when he creates scenes in which children are born under uncommon circumstances: A queen is chased from her castle, a mysterious lady has left her home to conceal her pregnancy from public knowing. Consequently, they have to put up with a delivery in the wilderness or on a backstreet. Luckily, there is always a merciful male stranger (whose perceptions and anxiety Lope describes so vividly that one is tempted to think he was calling to mind personal memories while making his verses) ${ }^{47}$. In the play El príncipe despeñado, this stranger appears in the guise of a countryman who finds the labouring queen holding on to a tree («asida a un olmo»48) and steps in to play the role of an emergency midwife. When describing the ensuing painful delivery in

39. Francisco Núñez, Libro del parto humano, fol. 28v.

40. «Mas si la que pare fuere gruesa y carnosa, más útil será que se eche en el suelo sobre la cara de tal manera que toque el suelo con la frente, teniendo las rodillas y piernas encorvadas arriba» (Núñez, Libro del parto humano, fol. 30r). As the passage is translated directly from Eucharius Rösslin's influential Rosengarten, published in 1513 (р. 28), there seems to have been wide agreement between German and Spanish doctors.

41. For medieval traditions in Andalucia, which in rural areas persisted until the 20th century, see Arjona Castro, 1991, p. 93.

42. Ruices de Fontecha, Diez privilegios para mujeres preñadas, fol. 144v. When was the birthing stool introduced in Spain, how widespread was its use? It seems that it was considered a recent habit but the issue needs a detailed discussion in an exclusive study (see for instance Núñez, Libro del parto humano, fols. 28v-29f). According to Rubio (2010, p. 101), physicians to the royal chamber and midwives first tried out a birthing stool when the Portuguese princess María Manuela, first spouse of Philip II, gave birth to Don Carlos in 1545. Many years later, Philip still thought that the use of the new technique was responsible for his spouse's death. I doubt, however, whether «colocar a la parturienta tumbada» would have been considered an alternative at that time, as María José Rubio suggests.

43. Ruices de Fontecha, Diez privilegios para mujeres preñadas, fols. $28 \mathrm{v}-29 \mathrm{r}$.

44. Ruices de Fontecha, Diez privilegios para mujeres preñadas, fols. $123 \mathrm{v}$ and $127 \mathrm{v}$.

45. For medieval traditions in Andalucia which in rural areas persisted up to the 20th century see Arjona Castro, 1991, p. 93.

46. See also Aichinger, 2015

47. For Lope de Vega's personal involvement in the deliveries of his children, some of them quite arduous it seems, see Colón Calderón, 2002, pp. 77-78.

48. Lope de Vega, El príncipe despeñado, p. 136, v. 989. 
much detail: sweat, panting, dishevelled hair 49 , Lope never leaves out one specific aspect: the lady, in need of support and throwing all shame to the wind, twines her hands and arms around the stranger's neck in the last stage of birth ${ }^{50}$. This, of course, is fiction. We might nevertheless deduce that parturition without the physical endorsement of another human being simply was not conceivable for the playwright ${ }^{51}$. In the heat of action his labouring protagonists do not care about the fact that they are dealing with men, and with strangers at that ${ }^{52}$.

Some 40 years later, the playwright and novelist Antonio Enríquez Gómez, returned to the issue, in a work that belongs to the picaresque genre. It is titled $E$ I siglo pitagórico y la vida de Don Gregorio Guadaña and was published in 1644. By contrast with Lope, Enríquez Gómez depicts home confinement. The mother is a midwife herself, the «cheerleaders» all belong to the female sex. So here again, childbirth is described as an act that should be fostered and hailed by the neighbourhood. The hearty description is given from the angle of an unborn first-person narrator and goes as follows:

[...] llenóse la cuadra de vecinas: las cuales para hacer compañía a mi madre cuando ella pujaba para echarme de sí, pujaban todas, y algunas parían antes que mi madre ${ }^{53}$.

49. Lope de Vega, El mayorazgo dudoso, p. 107

50. The scene is first represented with the protagonist disappearing in the crucial moment: ELVIRA Pues camino sin provecho./ ¡Ay, Virgen! DANTEO ¡Válgame Dios!/ sentaos mi señora allí./ ELVIRA No me dejes de tener./ DANTEO Partera me quiere hacer./ ELVIRA ¡Ay! DANTEO ¡Esforzaos!/ ELVIRA ¡Ay de mí! (Métanse entre los árboles [...]). Interestingly the last four verses were crossed out in the manuscript and glossed with a NO. They were maybe not considered adequate for representation by a censor. However, shortly afterwards in the play, the circumstances of delivery are narrated by the shepherd to his companions: "DANTEO [...] la hora del parto llega / y sentándose en el campo / que yo la tenga me ruega, / tengola, suspira, gime / más grave que descompuesta, / que aunque viene en traje humilde, / no es posible que lo sea, / trábame el cuello y las manos / con una vergüenza honesta, / más fuertes necesidades / atropellan la vergüenza [...] (Lope de Vega, El príncipe despeñado, p. 122, vv. 913-918; p. 127, vv. 1005-1015). 51. According to a late medieval Spanish writer, the Virgen Mary also chose a non-lithotomy position, that is, she was not lying on her back. But the assistance came from angels: «[...] no fue menester partera, mas los dichos príncipes angelicales tomaron al salvador saliendo del precioso cuerpo de la Virgen y pusieronselo delante la cual segund dicho es. Estaba de rodillas teniendo los ojos y las manos alzadas contra el cielo. E así como la gloriosa vio aquel glorioso fijo acatólo firmemente en la cara con muy grand deleite y hobo el mayor gozo que jamás había habido.» Eiximenis, Libro de la vida de nuestro Señor Jesuchristo, fol. 90r.

52. A document issued in Zaragoza, AD 1490, describes the delivering woman as „echada de spaldas en los brazos y piernas del [...] senyor Martín de Palomar y de Guerra [her brother-in-law] who is seated on a stool. There are two midwives, one on another stool between the woman's opened legs, which are covered with a cloth, the other is kneeling in front of the parturient (García Herrero, 1989, p. 291).

53. Kreuzwieser, 2013, pp. 20-23, cites examples from 20th century Latin American literature, where the phase of expulsion is accompanied by the rhythmical repetition of the word «puja». For Muslim communities in Spain see Fernández Medina, 2014, pp. 268-275. 
The baby is situated in the uterus with its feet pointing down and the midwife predicts a difficult delivery. A surgeon and some doctors are called for, the use of a crotchet $^{54}$ is suggested while the choir of female voices increases in volume:

Entonces las vecinas, unas Ilorando, otras rabiando, decían: puje, señora comadre que le va la vida; salga de pies o de cabeza. [...] Pidió pujos la comadre, y a dos rempujones me arrojó mi madre de la ventana de la muerte a la calle de la vida. Empezaron todos a reír, y yo a llorar ${ }^{55}$.

Despite the satirical undercurrent of the whole passage, it points to childbirth as a communal and concerted effort and endeavour.

\section{THE VIRGIN-MIDWIFE. ROLE MODELS, NARRATIVES AND VISIONS}

Childbirth ritual aims at affecting the body of the woman in labour. But the mind is always involved, insofar as women are encouraged to experience the processes of their bodies in accordance with specific role models. Or simply put: they should listen to stories even when embarking on the demanding enterprise of birthing; they should fantasize with good stories, they should, in the very special state of mind they are in, even imagine the «presence» of divine helpers. The midwife, recommends Ruices de Fontecha, should cheer her up with

buenos ejemplos [italics W. A.], de acontecimientos felices, así de pobres, como ricas, flacas, sanas y enfermas que parieron muy bien, aunque se detuvieron, y persuadiéndolas a que no es verdad aquel proverbio recebido, parto largo y hija al cabo, contándoles ejemplos de mujeres que después de largos partos, tuvieron hijos muy graciosos y fuertes, porque esto hace mucho al caso, y tal lo aconsejan todos los autores arriba citados 56

The most famous stories revolved around the Virgin Mary, mother of Christ, but also powerful advocate for and helper of all women involved in childbirth. In predominantly Catholic regions we still celebrate the festivities associated with her life and Assumption to heaven but we rarely associate her with the fate of women who expect childbirth. The opposite applies to Baroque Spain. At that time, Saint Mary was perceived first and foremost as a woman who gives birth. There is rich evidence for this view, in personal letters, in collections of miracles, in the biographies of queens or female aristocrats or even in dramatic texts of the age ${ }^{57}$. What we still

54. See for this instrument Wilson, 2013, p. 225.

55. Antonio Enríquez Gómez, El siglo pitagórico y la vida de Don Gregorio Guadaña, pp. 65-66.

56. Ruices de Fontecha, Diez privilegios para mujeres preñadas, fols. $127 \mathrm{v}-128 \mathrm{r}$. See also Francisco Núñez, Libro del parto humano, where the author writes: «se debe recrear [la parturienta] con palabras agradables y prometiendo buena esperanza de feliz y venturoso parto de varón» (Núñez, Libro del parto humano, fol. 30r). We will not dwell on the male chauvinism which informs these passages. Differences in the attention and care given to female or male infants would be worth another study.

57. Testimonies have been synthesised and discussed in the work of Carlos Varona, 2006, 2007, 2008 and Usunáriz, 1999, 2016. See also Aichinger, 2015, 2016. For the importance of Saint Mary in Islamic 
need is a close examination of the times and places where Marian narratives were reminded and constituted the backdrop of an analogous human experience.

Let us look at two well-known examples first, both included in the Milagros de Nuestra Señora by the Spanish monk Gonzalo de Berceo. Gonzalo's collection draws on Latin sources. The stories he recast in Castilian language were read and recited all over Europe. The first example is now labelled as Un parto milagroso ${ }^{58}$ or also La preñada salvada por la Virgen. It is set in France, at the Mont Saint Michel sanctuary. There, a pregnant woman is cut off from her companions by the rising tide and seeks shelter from the waters (mind the symbolic value of water in rhythmical movement!) in a chapel. Some hours later she joins the other worshippers with a baby in her arms; the Virgin Mary herself has stopped the flood and delivered the baby ${ }^{59}$.

The Virgin also takes care of unintended pregnancy. Gonzalo de Berceo conveys an idea about how this had to be done in a female religious community. We find it in the story of the pregnant abbess - La abadesa preñada-, which tells the straits of an abbess who attempts to keep pregnancy and childbirth secret ${ }^{60}$. She has become pregnant as a consequence of a single slip in an exemplary religious life. Her fellow sisters notice the change in the shape of her body and threaten to inform the bishop whose visit to the monastery is impending. On the eve of this terrifying event, the abbess retires to her private oratory in great anguish and invokes the Virgin's help. Saint Mary descends with two angels, delivers the baby -in a painless birth -and has the infant transferred to a hermit's hut by her assistants. The stories belong to the 13th century culture, similar ones can be found in Golden Age collections of miracles. A recent edition includes the story of an adulteress rescued from shame and dishonour by the Virgin by means of a secret nocturnal delivery. It occurs by the end of the 15th century. We will not comment on details here. Still, the central passage is worth quoting:

E ella estando con [el marido] en la cama la mesma noche que él llegó, viniéronle los dolores del parto. Y saltando de la cama, como que iva a otra cosa, salió de su cámara y púsose delante una imagen [de la Virgen] que tenía allí [...]. E acaesçió cosa maravillosa e digna de loor y memoria: que -a desora y sin algund dolor- parió un niño, el qual se desenvolvió y salió de la tela donde están enbueltos, como si partera [italics W. A.] toviera que esto fiziera ${ }^{61}$.

and Morisco communities see Fernández Medina, 2014, pp. 260-267. As to miracles as sources for the history of medicine and culture see also Foscati, 2017.

58. Gonzalo de Berceo, Obras completas, pp. 79-83.

59. Gonzalo de Berceo, Los milagros de Nuestra Señora, pp. 144-150.

60. Gonzalo de Berceo, Los milagros de Nuestra Señora, pp. 159-176.

61. Los milagros de Nuestra Señora de Guadalupe, pp. 720-721. I am very grateful to José Aragüés Aldaz for bringing this text to my knowledge. 
The Virgin herself takes matters in hand, she is thought of as a midwife ${ }^{62}$-superhuman, yet highly competent in practical things ${ }^{63}$. Her intervention shows immediate effects on earthly issues. Let us not dismiss these stories and their rather naturalistic view of miracles as childish manifestations of pre-rational stages of civilization. Rather, they inform us about the power of storytelling and what is more: about the cognitive function of stories and the power of imagination in extreme situations: Early modern Spanish people were much more prone to construct mental images of divine figures than we are today. Consequently, in altered states of conscience, they could be projected onto the outside world and turned into divine visions. The mind of a delivering woman, flooded with endorphins, was probably even more inclined to do so.

\section{PLAYING CHILDBIRTH}

Rituals are a condensation and reflection of cultural values, as well as a space where these values are renegotiated. While we have tried to assess the relationship between childbirth and ritual, at several points we have come across professional theatre. Spanish playwrights often reflected on extraordinary circumstances of birth as a starting point for an extraordinary life. Thereby they also conveyed manifold aspects of what was considered the canonical handling of the first and decisive moments of life ${ }^{64}$. Interestingly, people also felt the desire to reflect on the culture of birth in the playful context of feasting. Such an occasion was primarily offered by carnival. During this special period people staged their own private «comedies». When several revellers got together on Shrove Tuesday, the suggestion «Juguemos a la parida»/ «Let's play childbirth» could be one of their choices for entertainment. This was followed by a casting in which roles were distributed by drawing lots. There had to be a woman who gave birth, of course, and a midwife. A male player was pressed into the unwelcome role of the emerging creature and subsequently wrapped up in a sheet so that he could not move his hands or feet anymore. Another man (mind the detail!) would sustain the delivering actress. Thereafter, waters breaking was enacted (by way of spilling a jug of water over the «foetus») as well as the delivery of the «child» from under the skirts of the «childbearing woman» ${ }^{65}$. The

62. Gonzalo de Berceo uses the epithet «buena madrina» (Gonzalo de Berceo, Los milagros de Nuestra Señora, ed. Brian Dutton, p. 146).

63. Baroque authors, who adapted the gospel to the taste of their age even saw Mary as assisting when her cousin Elisabeth was giving birth to the infant who would be known as Saint John Baptist (Usunáriz, 2016, p. 322). The connection between the life of Mary and Jesus on one side and that of contemporary women on the other was also established through images: The front cover of Carbón's treatise Libro del arte de las comadres o madrinas (1541), for instance, shows the biblical Visitation scene.

64. See Aichinger, 2014, 2015, 2016.

65. The description can be found in La Tarasca de parto en el Mesón del Infierno y días de fiesta por la noche, written by Francisco Santos and first published in Madrid in 1672 (Melero Jiménez, 2013, pp. 52, 620-621 and 689; for an introduction to the life and work of Santos see García Santo-Tomás, 2014). The author reports: «Digo que son juegos bacanales. Júntanse en otra casa diversas personas, ¿qué haremos? ¿qué no haremos?, juguemos a la parida. Echan suertes, y tócale al uno la comadre, otra mujer la parida, un hombre a quien echan lo pesado del juego lo que nace [sic], otro tiene a la que pare, y deste 
new-born baby was scolded by the resentful mother while the other players pricked it with needles ${ }^{66} \ldots$ Modern parents imagine their baby's looks and character on the base of ultrasound images and medical findings ${ }^{67}$. People from Early Modern Spain certainly had their own medical procedures and they were actually quite confident as to their efficacy ${ }^{68}$. But they also felt the necessity to «reformulate» childbirth in a ritual context, to conjure its risks and its unpredictability by way of role playing and a sort of psychodrama. Thereby some canonical elements of delivery and the social forms which surrounded it were affirmed in a carnevalesque atmosphere.

\section{DOCTORS, MIDWIVES, NUNS AND VOCIFEROUS NEIGHBOURS}

Four groups had their say and interacted in childbirth: mothers-to-be, midwives, doctors and ecclesiastics ${ }^{69}$. How did they cooperate, who was in charge of the ritual aspects of childbirth, can we detect conflicting opinions about what ought or ought not be done? ${ }^{70}$ Did 17 th century authorities strive to remove female assistance in childbirth, or, at least, to get midwives under the control of what the emerging scientific discipline of obstetrics would dictate? ${ }^{71}$ We know that early modern Spanish

modo se parten los puestos, y reparten los cargos: la que quiere parir empieza a hacer los ademanes, viene la comadre, y al que ha de nacer, le lían en una sábana de tal forma, que no puede jugar ni pie, ni mano, y solo se le ve la cara.

Llega la hora de parir, previénese lo necesario, y puesta muy hueca de faldas, mete debajo al tonto, liado como pellejo de vino, quiebra la fuente con un cántaro de agua, que todo cae encima del pobre que nace, destápale en forma de nacido, y luego dice la parida: ¡Eres tu quien tantos dolores me ha costado! ¡O nunca acá vinieras! Y diciendo y clavándole un alfiler, o aguja, lo que prevenido tiene, le hace echar un reniego, el juramento y el por vida, sin poder jugar más de la lengua, porque en lo demás tan liado está, que no es dueño de sí.

Los demás que pidiendo andan albricias, recogen alfileres, y van a picar al pobre que ha nacido, con que viene a quedar de tal forma, que lo que empezó juego, acaba en pesadumbre. Por cierto, buen entretenimiento, buen modo de disponerse para entrar en el día santo» (Melero Jiménez, 2013, p. 478, orthography modernized by W. A.).

66. The cruelty and vengefulness exercised against the infant is most likely due to the logic of the comic «genre» and contrasts with those passages in medical treatises that ask for tenderness and care in the treatment of the child. Núñez warns parents to «guardarse mucho de maldecir al niño cuando Ilora, ni encomendarlo al demonio», y añade: «como muchas mujeres crueles algunas veces lo hacen» (Núñez, Libro intitulado, fol. 160r-v). Carbón writes in his Libro del arte de las comadres o madrinas, fol. 60r: «Ténganlo limpio y repose en su cuna con ligero movimiento y canciones suaves y amorosas [...]». 67. For the perception of the unborn as a crucial research question see Duden, 2002.

68. See for example Ruices de Fontecha, Diez privilegios para mujeres preñadas, fol. 128r.

69. In some cases also fathers, relatives or witnesses who acted in the name of political and juridical interests (García Herrero, 1989).

70. Most of what we know about 17th century Spanish midwives was written down by men and a great part of it by doctors. Queens, aristocrats, religious women, nuns and abbesses probably could devote more time to writing than midwives could, so they give us some additional insight. Nevertheless, there is a significant male bias in what we can put together about the procedures during parturition.

71. There is a lot of evidence that such a process took place during the centuries to come, according to Gélis it started by the end of the 17th century (Gélis, 1989, pp. 185-186). But early modern doctors had no idea about these long-term developments. Neither did they view themselves as part of such a process - for the simple reason that they could not look into the future- nor as agents of a development 
authorities established stricter criteria for the exercise of midwifery and medical examinations for women who wanted to become members of the guild. Treatises written by male doctors aimed at instructing midwives not in Latin, but in the language they could understand, that is in Spanish. Carbón also complains that new-borns often died a short time after birth because their mothers, in cases of diseases, turned to midwives for help instead of consulting a doctor ${ }^{72}$. But did these dispositions and comments immediately lead to loss of female skills and authority in matters of childbirth? Did they really abandon longstanding habits and practices? The problem cannot be discussed in all its dimensions here, ${ }^{73}$ we will limit ourselves to the symbolic or what seem to be merely symbolic aspects of birthing under normal circumstances. Thereby we will draw again on the treatises by Carbón, Núñez and Ruices de Fontecha.

These authorities agree upon two main points: First, for reasons of decency and for what might be labelled as the psychological aspect, female assistance in childbirth is indispensable. It is therefore all the more important that midwives should be well instructed. They should also have an excellent reputation and show all the virtues required by the office. Second, midwifery cannot be exclusively taught on the base of what is preserved from the times of Hippocrates, Galen and other ancient authorities. Childbirth practice has to be constantly enriched by experience. We can find many examples that point to doctors' experience in the field and to what they thought to be -or had observed to be- the usual practice of comadronas ${ }^{74}$. The predominant impression is one of respectful collaboration, where male writing did not aim at abolishing what midwives did or knew but to combine bookish and experiential knowledge in an effort to collect everything deemed to be the best practice of the time and to put it at the service of less experienced professionals of both sexes ${ }^{75}$. Carbón, Núñez and Ruices de Fontecha at some points even question the

set off to achieve the destruction of female knowledge (for the same problem in English historiography see Wilson, 2013, p. 213). As a matter of fact a 17th century Spanish author simply could not imagine childbirth without female professionals. What is more, circumstances of this specific historical time made political and academic authorities even more aware of the important tasks midwives were entrusted with. Not only did they procure the success of birth in times of demographic crisis, they frequently had to testify at court. In addition, they watched over catholic orthodoxy in Morisco communities (See Bleda, Vida y milagros del glorioso San Isidro el Labrador, p. 60; Fernández Medina, 2014, pp. 254-260, Fernández, 2007, González Castrillo y González Castrillo, 2015). It was one purpose of the Concil of Trent (1545-1563) to push back ritualistic forms which were not sanctioned by the Church (Usunáriz, 2016, pp. 341-343). This would be the subject matter for another study as would be the complex interaction between popular and official Church culture. Such a study would also look at the ways in which rituals of childbirth in non-Christian or Converso communities was perceived and commented.

72. Carbón, Libro del arte de las comadres o madrinas, fol. 61r.

73. For an excellent introduction see Usunáriz, 2016, pp. 329-359.

74. Carbón, for instance, repeatedly refers to cases that he has witnessed in his home town, Palma de Mallorca.

75. Ruices de Fontecha, Diez privilegios para mujeres preñadas, fols. 128r-v. 
value of ancient authorities and highlight their shortcomings while underlining the knowledge, good sense and practical wisdom they have observed in midwives ${ }^{76}$.

Time and again, they emphasize the importance of the human factor in childbirth assistance. A good midwife should give mental support through her cheerful and sanguine temperament, through the examples and stories she calls to mind. All this was meant to keep the expectant mother in good spirits and to prevent her hopes and physical forces from declining.

However, some criticism crept into the writings of academic authorities. Let us take a brief look at those related to our main topic, that is: the ritual proceedings in the birthing chamber. Fontecha dedicates some lines to the «soundtrack» of parturition. He admonishes all those who are present at delivery to stand aside and to encourage a happy outcome by praying. But they should not obstruct birthing with a display of screaming and tumultuous performances. He attributes such boisterous behaviour to old women:

Anime mucho la comadre a la que pare, consuélela mucho, y los presentes acudan a Dios, pidiendo muy de veras el buen suceso, sin voces y alharacas, como suelen hacer algunas viejas [italics W. A.], donde pensando que ayudan, desaniman a la pobre de la que pare, quien la tiene por detrás, la tenga con mucho cuidado y blandura $[. . .]^{77}$

What can we make of this passage? Are we confronted with a random testimony which highlights personal experiences or just repeats some gossip and false imputations? Or, else, does professor Ruices de Fontecha record a moment of historical change and a clash of conflicting attitudes? There would then be an older and more sociable atmosphere - with clamorous female relatives and old Celestinas from the neighbourhood who hailed the expulsion of the foetus with the rhythm of their breathing, gasping, shouting and noisy invocations. This atmosphere would stand against a newer one, with new forms of control and assistance, where the involvement of the community declined and the mother became more isolated in her plight or maybe more focussed on what a professional midwife told her to do.

Criticism against «some strange old women» («algunas viejas extrañas») is also pronounced in the work of Carbón. Contrary to Ruices de Fontecha, he explicitly links clamour and incantations to the problem of heresy: "Creeme», he writes, «que vi una comadre vieja, la cual su cabeza mirando el cielo mil veces abriendo la boca decía no sé qué palabras y la he visto en esta ciudad [Palma de Mallorca] por herética inquirir, y ella confesar mil errores y hechicerías.» Nevertheless, Carbón does not want to bar all rituals from the birthing room: «Confíe en Jesu Christo», he continues

76. For instance, Ruices de Fontecha (Diez privilegios para mujeres preñadas, fol. $114 \mathrm{v}$ ) praises those midwives who can diagnose the imminence of birth by feeling the mother's pulse. - a question of rhythm again! (For the importance of the matter in the Middle Ages see Schmitt, 2016, pp. 122-123.)

77. Ruices de Fontecha, Diez privilegios para mujeres preñadas, fol. 144v. 
«y en la Virgen María su madre. Invoque la bienaventurada santa Margarita y tenga santas reliquias sobre el vientre» ${ }^{78}$.

The display of religious symbols always depends on some form of instituted or self-appointed authority. It is not surprising, hence, that we find nuns bustling and even commanding in the birthing chamber. In Madrid, in the early years of the 17th century, the nun Mariana de Jesús enjoyed a great reputation for her prophetic gift, which she also put at the service of childbearing ${ }^{79}$. But this would be another story.

To sum up, the authority of midwives could be questioned by doctors and curtailed by religious «thought technicians» (as Victor W. Turner would call them). We have nevertheless good reason to insist on our main argument: Despite occasional criticism and interference in male writing on childbirth from Early Modern Spain, there is no clear movement against the female midwife as an institution, a source of knowledge and a mistress of ritual.

\section{CONCLUSIONS}

Doctors and midwives of Golden Age Spain were not blundering amateurs who would just let women die under their hands, because they did not know or because they did not care. However, we can observe the close interplay of practices which we would now categorize and keep separate as «medical», «symbolic», «psychological» or «religious» ones. Thereby, we tend to give greater importance to those remedies whose effect we can measure and express in numbers. But in a time in which scenes of the passion of Christ were depicted on a birthing stool or the life story of Saint Margaret was written on a birthing girdle, both spheres closely cooperate and it is difficult to draw a clear line between body and mind, physiological or psychological support 80 .

Some of the old methods have been rediscovered by those who felt unsatisfied with the way childbirth was and widely is administrated in modern hospitals. As Carbón, Núñez or Ruices de Fontecha did, they point to the importance of rhythm and timing. They seek to awaken all the strength that is available in a delivering woman's body and mind. They want her to give birth ${ }^{81}$. They think it unwise to make

78. Carbón, Libro del arte de las comadres o madrinas, fol. 38r. For the question of midwifery and heresy see also Surtz, 2006 and Fernández Medina, 2014, pp. 250-254.

79. Her biographer reports a case in which midwives and doctors struggled in a difficult birth and were going to administer a potion with dangerous side effects for the childbearing woman. But they were overruled by sister Mariana who forbade the use of the remedy. Subsequently, the parturient could be delivered from a stillborn child, an outcome viewed as a «buen suceso», a good occurrence (Salvador, La azucena de Madrid, la venerable madre Sr. Mariana de Jesús, pp. 355-356).

80. Wilson, 2013, pp. 218-223

81. The same interest can be found it the book Spanish doctors heavily drew on, Eucharius Rösslin's Rosengarten, published in 1513. Time and again, Rösslin's work uses expressions which highlight female strength: «mit guter Kraft ihres Leibs» («with the good strength of her body»), «gute[r], starke[r], kräftige[r] Atem» («good, strong, vigorous breath»), «also dass sie wohl in der Geburt mag [...] drucken und arbeiten» («so that she may well press and work during birth») (Rösslin, Eucharius Rösslin's Rosengarten, p. 22). 
a parturient lie on her back turning her body into the passive object of medication, instruments and techniques. They insist on the active part a healthy woman should take in delivery instead of being pushed into the clinical world of disease and worstcase scenarios. In addition, they share the belief that a mother-to-be should be fed with confidence and with good stories, stories which raise her hopes and trigger her energies. So there are plenty of things we can learn from the Siglo de Oro.

Yet there is no way we could fully grasp Spanish Golden Age birthing experience. Early modern Spanish women and men lived in bodies which were in many ways different from ours, they had different ideas about health, risk, danger and about what one could expect on earth and in heaven. Their senses received different stimuli, their imagination was not shaped by ultrasound pictures of the unborn foetus and by medical tests ${ }^{82}$.

What they did and what they endured was guided and interpreted by symbols and scripts which we still know. But it would be difficult to assess the exact impact on every single one of their thoughts, feelings or actions, an impact that lasted from the cradle to the coffin. Childbirth infused early modern humans with awe and fear, many a woman dictated her last will and testament while she was expecting ${ }^{83}$. But birth was also celebrated as the fullest expression of life, epitomising cosmic powers and mirrored by the fertility of springtime and nature, the life-giving elements or the energies of the planets ${ }^{84}$. Midwives and doctors believed that they could offer a great spectrum of effective remedies to facilitate delivery and to prevent its dangers. Yet, they knew that all too often they had to surrender to powers they could not control. To what extent were they -or their ignorance of things we do know todayresponsible for the high mortality rate of mothers and infants? What was the share of other factors: malnutrition, plagues, cruelty exerted on unmarried mothers, hard work, or the increasing difficulty of the social elites to produce healthy offspring, a fact that was already commented on by contemporaries? ${ }^{85}$ It seems difficult to give a fair judgement of early modern obstetrics in the complex interplay of body, mind, culture, knowledge, skill, care and circumstances ${ }^{86}$. Notwithstanding, it is important to listen to the strange voices from far away Golden Age Spain. They could contribute to a deeper understanding of a crucial time in European history and to a clearer insight into our own shared myths, thus inviting us to reflect on the symbols,

82. See Duden, 2002, pp. 46-48.

83. Examples can be found among aristocrats and commoners. For queen Margarita de Austria see Diego de Guzmán, Vida y muerte de Doña Margarita de Austria Reina de España, fol. 121r. For the life of women recorded in Granada in the 16th and 17th century see for instance Galera Mendoza, 2017, pp. 391-396.

84. See Alonso de Carranza, Disputatio de vera humani partus naturalis et legitimi designatione. Carranza's treatise will prove essential for further inquiries into the history of the interpretation of birth. 85. See Gómez Alfaro, 2010, p. 595. Modern historians give various reasons: queens and duchesses married young, lived through their first pregnancy at a very young age; they did not breastfeed, so there were shorter intervals between periods of gestation. As consanguineous marriage was frequent and sometimes practiced in consecutive generations, their bodies bore the consequences of impoverished genetic material (see Bennassar, 1983, pp. 22-23; Bennassar, 1985, pp. 340-344, Mitterauer, 2013. 86. See also Wunder, 1992, pp. 156-159; Usunáriz, 1999, p. 331 
paradoxes, absurdities, conflicts and tensions that are present and negotiated in modern birthing rooms ${ }^{87}$.

\section{BIBLIOGRAPHY}

Aichinger, Wolfram, «El parto violento en Calderón y el dramatismo del parto en la España del Siglo de Oro», in La violencia en el teatro de Calderón, ed. Manfred Tietz and Gero Arnscheidt, Vigo, Academia del Hispanismo, 2014, pp. 17-36.

Aichinger, Wolfram, «Partos de reinas y peripecias de reinos en la comedia de Lope de Vega», in Tiempo e historia en el teatro del Siglo de Oro. Actas selectas del XVI Congreso Internacional de la AITENSO, ed. Isabelle Rouane Soupault, Isabelle and Philippe Meunier, Aix-en-Provence, Presses universitaires de Provence, 2015, pp. 190-202.

Aichinger, Wolfram, «Geburt, Inzest, Endogamie und das Monströse im Werk Calderóns», in ed. Jörg Türschmann and Matthias Hausmann, Das Groteske in der spanischen und lateinamerikanischen Literatur, Göttingen, Vienna University Press/V\&P unipress, 2016, pp. 19-29.

Anonymus, Lazarillo de Tormes, ed. Francisco Rico, Madrid, Cátedra, 2003.

Anonymus, Los milagros de Nuestra Señora de Guadalupe (siglo XV y primordios del XVI): edición y breve estudio del manuscrito c- 7 del archivo del Monasterio de Guadalupe, ed. María Eugenia Díaz Tena, Mérida, Editora Regional de Extremadura, 2017.

Ariès, Philippe, Essais sur l'histoire de la mort en Occident du moyen âge à nos jours, Paris, Seuil, 1975.

Arjona Castro, Antonio, ed., El libro de la generación del feto, el tratamiento de las mujeres embarazadas y de los recién nacidos. Tratado de Obstetricia y Pediatría del siglo $X$, de Arib Ibn Sa'id, traducción y notas del Dr. don Antonio Arjona Castro, Sevilla, Sociedad de Pediatría de Andalucía Occidental y Extremadura, 1991.

Bayerri y Bertomeu, Enrique, La Virgen de la Cinta, Patrona de Tortosa, s. i. [Tortosa], s. n. [Cooperativa Gráfica Dertosense], 1989.

Bennassar, Bartolomé, La España del Siglo de Oro, Barcelona, Crítica, 1983.

Bennassar, Bartolomé, Histoire des Espagnols. T. I, VIe-XVIle siècle, Paris, Armand Colin, 1985

Bleda, Jaime, Vida y milagros del glorioso San Isidro el Labrador, hijo, abogado y patrón de la real villa de Madrid, Madrid, Imprenta de Tomás Junti, 1622.

Butler, Judith, Precarious Life. The Powers of Mourning and Violence, London/New York, Verso, 2006.

87. See for an introduction and further bibliography e.g. Van Hollen, 1994. 
Carbón, Damián, Libro del arte de las comadres o madrinas y del regimiento de las preñadas y paridas y de los niños, Mallorca, Hernando de Cansoles, 1541.

Carlos Varona, María Cruz de, «Entre el riesgo y la necesidad. Embarazo, alumbramiento y culto a la Virgen en los espacios femeninos del Alcázar de Madrid (s. XVII)», Arenal (Madrid), 12, 2006, pp. 263-290.

Carlos Varona, María Cruz de, «Representar el nacimiento. Imágenes y cultura material de un espacio de sociabilidad femenino en la España Alto-moderna», Goya. Revista de Arte 319-320, 2007, pp. 231-245.

Carlos Varona, María Cruz de, «Una propuesta devocional femenina en el Madrid de comienzos del siglo XVII. Simón de Rojas y la Virgen de la Expectación», in La imagen religiosa en la monarquía hispánica. Usos y espacios, ed. Jean-Pierre Étienvre, Madrid, Casa de Velázquez, 2008, pp. 83-99.

Carranza, Alonso de, Disputatio de vera humani partus naturalis et legitimi designatione, Madrid, Francisco Martínez, 1628.

Colón Calderón, Isabel, «Hacia una visión lírica de la realidad: La invocación a Lucina», in Estudios sobre tradición clásica y mitología en el Siglo de Oro, ed. Isabel Colón Calderón and Jesús Ponce Cárdenas, Madrid, Ediciones Clásicas, 2002, pp. 73-82.

Domínguez Moreno, José María, «El ciclo vital en la provincia de Cáceres: Del parto al primer vagido», Revista de Folklore, vol. 6a, num. 61, 1986, pp. 1-21.

Duden, Barbara, «Zwischen , wahrem Wissen' und Prophetie: Konzeptionen des Ungeborenen», in Geschichte des Ungeborenen. Zur Erfahrungs- und Wissenschaftsgeschichte der Schwangerschaft, 17.-20. Jahrhundert, ed. Barbara Duden, Jürgen Schlumbohm and Patrice Veit, Göttingen, Vandenhoeck \& Ruprecht, 2002, pp. 11-48.

Douglas, Mary, Purity and Danger. An Analysis of Concepts of Pollution and Taboo, London/New York, Routledge, 2002.

Eiximenis, Francesc, Vida de Jesucristo, Granada, Meinardo Ungut and Juan Pegnitzer de Nuremberga, 1496 [1409].

Enríquez Gómez, Antonio, El siglo pitagórico y la vida de don Gregorio Guadaña, Bruselas, Francisco Foppens, 1727 [1644].

Fernández, Enrique, «Tres testimonios del control y desplazamiento de las comadronas en España (siglo XIII al XVII)», Revista Canadiense de Estudios Hispánicos, 32.1, otoño 2007, pp. 89-104.

Fernández Medina, Esther, La magia morisca entre el Cristianismo y el Islam, Granada, Editorial de la Universidad de Granada, 2014.

Foscati, Alessandra, «Venire alla luce e rinascere. II cesareo da madre morta e il miracolo à répit nel tardo Medioevo», en Nascere. II parto dalla tarda antiquità 
all'età moderna, ed. Alessandra Foscati, Costanza Gislon Dopfel y Antonella Parmeggiani, Bologna, II Mulino, 2017, pp. 95-114.

Galera Mendoza, Esther, Mujeres en la Alhambra. Colección de documentos de los siglos XVI y XVII, Alcalá de Henares, Universidad de Alcalá, 2017.

García Herrero, María del Carmen, «"Administrar del parto y recibir la criatura": Aportación al estudio de Obstetricia bajomedieval», Aragón en la Edad Media, 8, 1989, pp. 283-292.

García Santo-Tomás, Enrique, «"Offspring of the Mind": Childbirth and Its Perils in Early Modern Spanish Literature», in Medical Cultures of the Early Modern Spanish Empire, ed. John Slater, María Luz López-Terrada and José PardoTomás, Ashgate, Farnham 2014, pp. 149-166.

Gélis, Jacques, Die Geburt: Volksglaube, Rituale und Praktiken von 1500-1900, München, Diederichs, 1989 [L'arbre et le fruit. La naissance dans I'Occident moderne XIV-XIXe siècle, Paris, Fayard, 1984].

Gil Saura, Yolanda, «Algunas notas sobre la capilla de la Cinta de la Catedral de Tortosa», Recerca, 12, 2008, pp. 97-128.

Gironella, José María, Un millón de muertos, Barcelona, Planeta, 1994 [1961].

Gonzalo de Berceo, Los milagros de Nuestra Señora, ed. Brian Dutton, London, Tamesis Books, 1980.

Gonzalo de Berceo, Obras completas, ed. Carlos Clavería and Jorge García López, Madrid, Castro, 2003.

Gómez Alfaro, Antonio, Escritos sobre gitanos, Barcelona, Asociación de Enseñantes con Gitanos, 2010.

González Castrillo, Rafaela and Ricardo González Castrillo, «El informe de Pedro Varaez sobre el oficio de comadre y la réplica de Francisco Antonio Díez de Cabrera», in Cultura de los Cuidados (edición digital), 19, 42, 2015, <http:// dx.doi.org/10.14198/cuid.2015.42.08>.

Guzmán, Diego de, Vida y muerte de doña Margarita de Austria, reina de España, Madrid, Luis Sánchez, 1617.

Harari, Yuval Noah, Sapiens. A Brief History of Mankind, London, Vintage, 2014.

Huertas Vázquez, Eduardo, «El singular escenario del barrio de la comadre», in Teatro español del siglo XVIII, Vol. 2, ed. Josep María Sala Valldaura, Lleida, Universitat de Lleida, 1996, pp. 525-548.

Knight, Suzy, «Devotion, Popular Belief and Sympathetic Magic Among Renaissance Italian Women: The Rose of Jericho as Birthing Aid», Studies in Church History, 2010, vol. 46, pp. 134-143.

Kreuzwieser, Renate, «"Tönend sollst du gebären". Eine rhythmisch akustische Betrachtung der Geburt», Vienna, Ms., 2013. 
Laget, Mireille, «La naissance aux siècles classiques. Pratique des accouchements et attitudes en France auX XVIIe et XVIIIe siècles», Annales E.S.C., 1977, pp. 958-992.

Lindorfer, Bianca Maria, Cosmopolitan Aristocracy and the Diffusion of Baroque Culture: Cultural Transfer from Spain to Austria in the Seventeenth Century, Diss. Phil. European Univ. Institute, 2009.

Martínez Kleiser, Luis, Guía de Madrid para el año 1656, Madrid, Imprenta Municipal, 1926.

Núñez, Francisco, Libro del parto humano, Alcalá de Henares, Imprenta Real, 1580.

Melero Jiménez, Elisa Isabel, Edición crítica de «La Tarasca de parto en el Mesón del Infierno y días de fiesta por la noche», Tesis doctoral, Cáceres, Universidad de Extremadura, 2013.

Mitterauer, Michael, «"Spanische Heiraten". Dynastische Endogamie im Kontext konsanguiner Ehestrategien», in Historische Verwandtschaftsforschung, ed. M. Mitterauer, Böhlau, Wien, 2013, pp. 149-212.

Pötting, Franz Eusebius, Diario del conde de Pötting, embajador del Sacro Imperio en Madrid (1664-1674), ed. Miguel Nieto Nuño, vol. 1, Madrid, Biblioteca Diplomática Española (Sección Fuentes, 1), 1990.

Répide, Pedro de, Las calles de Madrid, Madrid, Afrodisio Aguado, 1971.

Rodríguez, Martha Eugenia, "Costumbres y tradiciones en torno al embarazo y al parto en el México virreinal», Anuario de Estudios Americanos, t. LVII, 2, 2000, pp. 501-522.

Rösslin, Eucharius, Eucharius Rösslin's Rosengarten [= Der Schwangern Frauen und Hebammen Rosengarten]. Begleittext von Gustav Klein, München, Carl Kuhn, 1910 [1513].

Ruices de Fontecha, Juan Alonso de los, Diez privilegios para mujeres preñadas, Alcalá de Henares, Luis Martínez Grande, 1606.

Sakala, Carol, Amy M. Romano and Sarah J. Buckley, «Hormonal Physiology of Childbearing, an Essential Framework for Maternal-Newborn Nursing», Journal of Obstetric, Gynecologic \& Neonatal Nursing, 45.2, March-April 2016, pp. 264275. DOl: <http://dx.doi.org/10.1016/j.jogn.2015.12.006>.

Salvador, Pedro del, La azucena de Madrid, la venerable madre Sor Mariana de Jesús, Madrid, Imprenta Real de la Gaceta, 1764.

Sánchez, Magdalena S., The Empress, the Queen and the Nun. Women and Power at the Court of Philipp III of Spain, Baltimore/London, John Hopkins University Press, 1998.

Schmid, Verena, Birth Pain. Explaining Sensations, Exploring Possibilities: a Guide for Midwives, Chester-le-Street, Fresh Heart Publishing, 2011. 
Schmitt, Jean-Claude, Los ritmos del cuerpo y del mundo en la Edad Media, Salamanca, SEMYR, 2016.

Surtz, Ronald E., «A Spanish Midwife's Uses of the Word: The Inquisitorial Trial (1485/86) of Joana Torrellas», Mediaevistik, 19.1, 2006, pp. 153-168, <https:// doi.org/10.3726/83006_153>.

Usunáriz, Jesús M., «Nacer en el Antiguo Régimen. El ritual del parto en la Europa Occidental», Memoria y Civilización, 2, 1999, pp. 329-337.

Usunáriz, Jesús M., «El "oficio de comadres" y el "arte de partear". Algunos apuntes sobre Navarra: siglo XVI-XVIII», in Modelos de vida en Navarra de la temprana modernidad, ed. Ignacio Arellano, New York, IDEA, 2016, pp. 319-363.

Van Hollen, Cecilia, «Perspectives on the Anthropology of Birth», Culture, Medicine and Psychiatry, December 1994, 18.4, pp. 501-512.

Vega Lope de, El príncipe despeñado, ed. María Soledad de Ciria Matilla, Pamplona, Gobierno de Navarra, 1992.

Vega Lope de, El mayorazgo dudoso, ed. Jesús Gómez and Paloma Cuenca, in Comedias, X, Turner, Madrid, 1994, pp. 95-195.

Vega, Lope de, La Dorotea, ed. Edwin S. Morby, Berkeley and Los Angeles/Valencia, University of California Press/Castalia, 1958.

Vidal Franquet, Jacobo, «La Baixada de la Cinta, 500 anys. Algunes qüestions d'iconografia», Recerca, 12, 2008, pp. 11-64.

Wilson, Adrian, Ritual and Conflict: The Social Relations of Childbirth in Early Modern England, Farnham, Burlington, England/Ashgate, USA, 2013.

Worth, Jennifer, Call the Midwife. A True Story of the East End in the 1950s, London, Phoenix, 2012

Wunder, Heide, «Er ist die Sonn', sie ist der Mond». Frauen in der Frühen Neuzeit, München, C. H. Beck, 1992. 